Handbuch der deutsch-jüdischen Literatur 



\section{Handbuch der}

deutsch-jüdischen Literatur

Herausgegeben von Hans Otto Horch 
ISBN 978-3-11-028081-4

e-ISBN (PDF) 978-3-11-028256-6

e-ISBN (EPUB) 978-3-11-039564-8

\section{Library of Congress Cataloging-in-Publication Data}

A CIP catalog record for this book has been applied for at the Library of Congress.

\section{Bibliografische Information der Deutschen Nationalbibliothek}

Die Deutsche Nationalbibliothek verzeichnet diese Publikation in der Deutschen Nationalbibliografie; detaillierte bibliografische Daten sind im Internet über http://dnb.dnb.de abrufbar.

(c) 2016 Walter de Gruyter GmbH, Berlin/Boston Umschlagabbildung: HAKKI ARSLAN/iStock/Thinkstock Druck und Bindung: $\mathrm{CPI}$ books $\mathrm{GmbH}$, Leck @ Gedruckt auf säurefreiem Papier

Printed in Germany

www.degruyter.com 